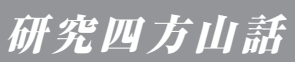

\section{思い出すことなど : 血小板膜糖蛋白について}

半田 誠

慶應義塾大学輸血・細胞療法センター

\section{はじめに}

1979 年, 血液内科を専門とすることに決めて, そ の際に縁あって大学医局の血小板グループに所属す ることとなった。その当時はわが国においては未だ 血栓・止血学の黎明期で, その後の血小板研究の華 やかなりし時代を迎える予感があったように覚えて いる. 安藤泰彦先生 (のち東海大学臨床検査医学教 授)を中心に, 渡辺清明先生 (のち臨床検査医学教授) と池田康夫先生 (のち血液内科教授) が脇を固め, 米 国流のフランクでかつ自主性を重んじる自由な䨌囲 気のもとで楽しく研究を始めることができたことは, 今から思うと幸運であった。当方のテーマは‘血小 板のコラーゲン線維への粘着に関する研究, で, こ れが学位論文となった。研究は病棟の仕事を片付け た後に，仲間同士で採血し合って血小板を分離する といったことから始まり, 深夜にまで及ぶことも多 かったが，充実していた，その後，1983 年からの米 国留学, そして, 1986 年からの長い教職人生を通じ て常に血小板が傍らにあり, 振り返ってみると研究 の楽しさと基礎から臨床に及んで血小板の面白さを 実感し続けることができた。

\section{血小板膜糖蛋白研究のきっかけ：とんだ思い違い}

1981 年頃, 新潟大学の高橋芳右先生から, その 当時世界的にみて数例しか報告のなかった血小板型 フォン・ビレブランド病 $(\mathrm{VWD}) 2$ 家系の血小板膜糖 蛋白解析の依頼が研究室にあり, 当方が担当するこ ととなった，その当時の研究手法は, 血小板 lysate をSDS 電気泳動法で展開したゲルを, クマシーブ ルーやPAS で蛋白部分や糖鎖を染色して, 検出され た糖蛋白 (GP) バンドのパターンを比較解析すると
いう極めて単純なものであった。主要な GP は相対 的分子量の高い順に番号を付けて GP I, GP II, GP III, GP IV ・ ・ と, さらに分子量が近似している もので異なるものでは $\mathrm{a}, \mathrm{b}, \mathrm{c} \cdot$ ・・などと添字を つけて命名され, 先天性血小板機能異常症である Bernard-Soulier 症候群 (BSS) では GP Ib が欠損してい ることが 1975 年に明らかにされ，それが血小板上の フォン・ビレブランド因子 $(\mathrm{VWF})$ の受容体であるら しいことがわかっていた，血小板型 VWD は血小板 側の原因により，VWFの異常であるVWDに類似し た表現型を示す。つまり，GP Ibの異常が患者の血 小板で予想されていた。そして, 実際ふたを開けて みると, 常染色体優性の遺伝形式を示す 4 人の患者 に限ってはすべて, 通常は一本のバンドである GP $\mathrm{Ib}(\alpha$ 鎖 $)$ が, 易動度の異なる二つのバンド (doublet) で構成されていることがわかった。一つは健常対照 と同じ分子量 (GP Ib)で，もう一つはそれょり若干 分子量の低いバンド $(\mathrm{GP} \mathrm{Ib}$ ') であった。 そのときは 大騒ぎとなり，まさにこの $\mathrm{GP} \mathrm{Ib}$ ’が疾患の病因とな る分子異常 (gain of function) を直接反映するものと 考え，この結果を含んだ論文が 1984 年に発表され るに至った ${ }^{1)}$.しかしこの推測は，とんだ思い違いで あることが後に明らかとなった，GP Ib $\alpha$ 鎖 $(145 \mathrm{kDa})$ の細胞外部分 $(130 \mathrm{kDa})$ は, トリプシンの限定分解 により, $\mathrm{N}$ 末端を占める $45 \mathrm{kDa}$ 部分と糖鎖の極めて 豊富な C 末端を占める Macroglycopeptide(MGP)に 分断される。そして, MGPにはアミノ酸 13 残基で 構成されたリピート (variable number tandem repeat: VNTR) が存在，そのリピート数がそれぞれ $4 ， 3 ， 2$, 1 個保有して，この順に分子量の低くなる 4 種類の バリアントが存在する ${ }^{2}$. つまり，このとき検出さ れた異常バンドは, 後に明らかにされたこの疾患の 分子異常 (Val239 $\rightarrow$ Met 変異)に強く連鎖したVNTR 
であったわけである31.いずれにしろ，この発見を きっかけに, VWF 研究のメッカであるカリフォル ニアの Scripps 研究所の TS Zimmerman 博士のラボ に留学し，その当時全く不明であったこのVWF 受 容体蛋白の構造と機能の関連の解明(VWF 結合部位 の同定)に挑戦することとなった。ちなみに，同時 期に奈良医科大学の藤村吉博先生 (のち奈良医科大 学輸血部教授) が留学され, VWF 分子の解析 (GP Ib 結合部位の同定)により大きな業績を残された。

\section{研究の成果 : 米国での経験}

その当時は未だ分子生物学的手法は一般に登場し ておらず，モノクローナル抗体を用いた蛋白レベル での免疫化学的解析が主流であった，純化した蛋白 を, 酵素による限定分解で断片化し, 種々の機能性・ 非機能性抗体のエピトープをその上に同定すること で，その分子の構造一機能連関を解析するという戦 略であった。しかしご多分に漏れずそうことは簡単 でなかった，その理由は，対象がVWFのような可 溶性血漿蛋白ではなく，ラボで技術的なノウハウを 全く保持していない水に不溶の膜蛋白であること だった。ラボが保有しているただ一つの抗 GP Ib 抗 体(LJ-P3)を頼りに，新たな抗体パネル作成の抗原 に用いる蛋白を, 抗体カラムを用いて精製すること から始めた。海軍病院から毎日のように届く大量の 血小板濃厚液と格闘し, 血小板の分離・洗浄から可 溶化, そしてLJ-P3 抗体カラムに続きWGAレクチン カラムを併用した精製法を確立するまでに 2 年程を 費やした。そして，新たに作成した二つの抗体，LJ$\mathrm{Ib} 1$ (強力な阻害抗体) と LJ-Ib10 (非阻害抗体, 後に トロンビン結合を強力に阻害することが判明)を加 えて, 固相化免疫分離法により, ヨード標識した精 製蛋白の酵素断片上の抗体エピトープを同定した. そして、VWFの結合部位が $\mathrm{N}$ 末端を占める $45 \mathrm{kDa}$ 断片に存在することを示す最終データが出そろった のは, 3 年が経過して帰国の準備をしようとしてい るときであった。当該論文はその年の秋に出版さ れ，終わりよければすべてよし，今までの苦労が報 われたと強く感じた ${ }^{4)}$ ，翌年には，共同研究者のワ シントン大学の千谷晃一先生(のち藤田保健衛生大 学教授)による当該 $45 \mathrm{kDa}$ 断片の全一次構造解析結
果が，他のグループによる cDNA クローニングの論 文と back to back で報告された ${ }^{5,6)}$. 時代はまさに蛋 白化学から分子生物学への転換期であった.

\section{研究テーマを探す：盲目的モノクローナル抗体 作成プロジェクト}

研究の質・量ともの圧倒的な彼我の差を米国で体 験したなかで, 新たな研究テーマをしばらく模索し た、そこで思いついたのは，血小板に対するモノク ローナル抗体を盲目的に作製し，そのなかから興味 ある抗体をつり上げて，それをツールとした研究を 立ち上げるというものであった。 マウスの免疫源と してまず用いたのは血小板膜の WGA レクチン結合 分画であった。最初は, 洗浄血小板固相化プレート を用いたスクリーニングにより 3 種類のクローン （WGA-1, -2, -3）を得たのみであった(のちに対応抗 原はそれぞれP-セレクチン, Integrin-associated protein, GPIba と判明). その後から宝酒造(片山政彦 研究員)の全面協力を得て, 免疫源やスクリーニング 法を工夫することでおよそ 50 種類に及ぶクローン を1987年から 1991年にかけて選択することができ， 多くの対応抗原分子が同定できた.

そのなかで予期しなかった分子の一つとして,

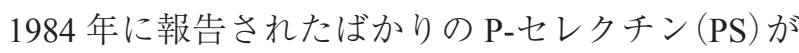
あった.PSは血小板の $\alpha$ 顆粒や血管内皮細胞の Weibel-Palade 小体の膜蛋白で, 細胞の活性化に伴 い細胞表面に移動し，白血球の接着の標的分子とな るセレクチンファミリーに属する。1989 年には, cDNA クローニングされ，その翌年には遺伝子構造 が明らかとなった ${ }^{7)}$ 。大変興味があることにはイン タクトの膜貫通型 $(\mathrm{mPS})$ 以外に，選択的スプライ シングにより膜貫通部分を含んだ領域をコードする エクソン 14 を欠失した可溶型アイソソフォーム (asPS)のメッセージが巨核球や血管内皮細胞に少な からず存在することであった。ちょうど時を前後し て，エピトープの交差しない二つの抗体の組み合わ せ(WGA-1 と PL7-6)によるサンドイッチ ELISA 法を 確立し，健常人の血漿中に 50-100 $\mathrm{ng} / \mathrm{mL}$ レベルの可 溶型 PS (sPS) を検出するとともに，さらに血小板の 微小血栓が誘発される血栓性血小板減少性紫斑病や 溶血性尿毒症症候群患者においては異常高值を示す 
ことを把握していた ${ }^{8)}$.1992年から1995年にかけて， われわれも含む複数のグループから，急性血栓性疾 患, 急性肺障害, 膠原病やマラリア感染症で血漿 sPS 濃度の異常高值 (500 ng/mL 以上) が報告された。 しかし, 他の細胞接着因子受容体と同様に, その分 子がコミットする病態において高值となる可溶型分 子は，蛋白分解酵素により細胞表面から truncateさ れたもの (tPS)であると思われていたが，何の証拠 も示されていなかった，そこで，膜貫通部分 $\mathrm{C}$ 末端 (14C) および細胞内部分の $\mathrm{N}$ 末端 $(15 \mathrm{~N})$ アミノ酸配 列に一致した合成ペプチドで免疫して，それぞれの ウサギ抗体を作製した，血漿および血小板 lysate か ら抗体(WGA-1) 吸着カラムで分離した抗原を免疫 ブロット法で抗ペプチド抗体との反応性を見たとこ ろ, 血漿由来のものは抗 $15 \mathrm{~N}$ 抗体に比して抗 $14 \mathrm{C}$ 抗体の反応性が著しく低下していた。一方, 血小板 由来のものは，両方の抗体に同等の反応性を示し た。これらのことは, メッセージレベルで予測され ていた asPS が生体内で実際の産物として産生されて いる可能性を示唆するものであった。 そこで, この ことを直接証明するために，大量のヒト血漿(14 L) および血小板 (120 単位) から抗体吸着カラムで抗原 を分離/精製(収量と収率はそれぞれ $1.6 \mathrm{mg}$ と $53 \%$, $4 \mathrm{mg}$ と 5.5\%であった)し, 酵素による分解断片の N 末端アミノ酸配列をシークエンサーで解析した。こ の仕事を担ったのは石綿紀久研究員(のち日産化学 開発部長) と理化学研究の瀧尾擴士博士であった。 その結果, 血漿および血小板には mPS や tPS ととも に asPS が少なからず存在していることが証明され た9)。まさに，米国で学んだ蛋白レベルでの力技の 勝利であった。

\section{おわりに}

自ら試験管を振っていた頃のことを思い出すまま に書いた。その当時の, GP Ib の研究は臨床(患者 の膜糖蛋白解析) から基礎へ，そしてPS は基礎か ら臨床 (sPS の測定)への方向性を図らずも示したも のである。それから 30 年あまりが経過し, 流動状態 下(high shear stress 依存性)で誘導されるVWF と GP $\mathrm{Ib}$ の動的な構造変化が, $45 \mathrm{kDa}$ 部分と VWF の GP Ib 結合部位である A1 ドメインのリコンビナント蛋
白で形成された複合体の結晶解析により明らかにさ れようとしている ${ }^{10)}$ 。一方, sPS 濃度は血栓性疾患 の信頼できる分子マーカとしての地位が確立されつ つある ${ }^{11)}$.どんなに些細なことでもそのときの研究 成果がその後の研究の進歩に貢献できたなら, 研究 者にとって大きな喜びである.

\section{文献}

1) Takahashi H, Handa M, Watanabe $K$, Ando $Y$, Nagayama R, Hattori A, Shibata A, Federici AB, Ruggeri ZM, Zimmerman TS: Further characterization of platelet-type von Willebrand's disease in Japan. Blood 64: 1254-1262, 1984.

2) López JA, Ludwig EH, McCarthy BJ: Polymorphism of human glycoprotein Ib alpha results from a variable number of tandem repeats of a 13-amino acid sequence in the mucin-like macroglycopeptide region. Structure/function implications. J Biol Chem 267: 10055-10061, 1992.

3) Takahashi H, Murata M, Moriki T, Anbo H, Furukawa T, Nikkuni K, Shibata A, Handa M, Kawai Y, Watanabe K: Substitution of Val for Met at residue 239 of platelet glycoprotein Ib alpha in Japanese patients with platelet-type von Willebrand disease. Blood 85: 727-733, 1995.

4) Handa M, Titani K, Holland LZ, Roberts JR, Ruggeri ZM: The von Willebrand factor-binding domain of platelet membrane glycoprotein Ib. Characterization by monoclonal antibodies and partial amino acid sequence analysis of proteolytic fragments. J Biol Chem 261: 12579-12585, 1986.

5) Titani K, Takio K, Handa M, Ruggeri ZM: Amino acid sequence of the von Willebrand factor-binding domain of platelet membrane glycoprotein Ib. Proc Natl Acad Sci USA 84: 5610-5614, 1987.

6) Lopez JA, Chung DW, Fujikawa K, Hagen FS, Papayannopoulou T, Roth GJ: Cloning of the alpha chain of human platelet glycoprotein Ib: a transmembrane protein with homology to leucine-rich alpha 2-glycoprotein. Proc Natl Acad Sci USA 84: 5615-5619, 1987.

7) Johnston GI, Bliss GA, Newman PJ, McEver RP: Structure of the human gene encoding granule membrane protein-140, a member of the selectin family of adhesion receptors for leukocytes. J Biol Chem 265: 21381-21385, 1990.

8) Katayama M, Handa M, Araki Y, Ambo H, Kawai Y, Watanabe $\mathrm{K}$, Ikeda Y: Soluble P-selectin is present in normal circulation and its plasma level is elevated in patients with thrombotic thrombocytopenic purpura and haemolytic uraemic syndrome. Br J Haematol 84: 702-710, 1993.

9) Ishiwata N, Takio K, Katayama M, Watanabe K, Titani K, Ikeda Y, Handa M: Alternatively spliced isoform of P-selectin is present in vivo as a soluble molecule. J Biol Chem 269: 23708-23715, 1994.

10) Blenner MA, Dong $X$, Springer TA: Structural basis of regulation of von Willebrand factor binding to glycoprotein Ib. J Biol Chem 289: 5565-5579, 2014.

11) Blann AD: Soluble P-selectin: the next step. Thromb Res 133: 3-4, 2014. 